\title{
RICH in the development of integrated curriculum in the English teaching mode and evaluation system
}

\author{
Yuanyuan Li \\ Leshan Normal University, Sichuan, Leshan
}

Keywords: English professional integrated curriculum development; RICH teaching mode; Evaluation system

\begin{abstract}
RICH teaching mode is based on the advanced education teaching theory of the new teaching mode, in English professional integrated curriculum development has an important status and role, as in the aspects such as teaching contents, teaching methods and teaching evaluation on the disadvantages of traditional teaching mode to substantially change, improve the teaching efficiency. And on teaching achievement evaluation pattern has formed a relatively complete system, the traditional English major integrated curriculum teaching assessment and evaluation is of great significance.
\end{abstract}

RICH teaching method is the result of the English teaching reform and development, is the progress of education teaching achievements, also be the power that promote English professional integrated curriculum development. RICH teaching method is produced in a particular context, the background mainly includes the following aspects:First of all, the current our country's emphasis on English education and reform, teachers of English teaching achievements obtained also have a strong motivation, so in order to improve the students' English achievements, research staff often get together to discuss the teaching problems, so as to contribute to the formation of small research group, the formation of these research groups undoubtedly provides the new teaching mode and method of fertile soil; Second, since a new round of teaching reform experiment of quality-oriented education is more and more attention in our country, to promote all-round development of students' various aspects quality requirements more and more urgent, this also accelerated the change of teaching mode.Anyway, since the generation of RICH teaching is the result of the current education development in our country, and has experienced more than ten years of teaching practice test, then it must have to adapt to the characteristics of English education teaching practice in our country, this feature can be English or other subjects in order to further the teaching reform.

\section{The connotation and theoretical basis of RICH teaching method}

The connotation of the RICH teaching method. RICH is one of the first letter acronym, among them, the R Research -based, meaning is based on the Research and exploration, I on behalf of the Integrated curriculum, which means language basic skill Integrated training course, $\mathrm{C}$ means Cooperative methodology, Cooperative learning method, $\mathrm{H}$ for Humanistic outcome, which means the improvement of Humanistic quality. This a few word accurately summarized the RICH the core characteristics and elements of teaching mode, that is, it is a kind of based on the small topic of research and exploration, through various forms of cooperative learning as the center of teaching methods, improve the students' basic language skills, and enhance the students' humanistic quality of the new teaching mode.Thus, RICH teaching mode is a challenge to traditional force-feeding teaching mode, is put forward aimed at the disadvantages of traditional teaching mode of strategy.

\section{RICH teaching in English major in the development of integrated curriculum teaching mode reform}

Traditional English education teaching mode, the teaching of English major is English teaching 
materials, teacher on the platform in the interpretation of the text language knowledge points, students in the audience and records, listen carefully for the text outside the cultural connotation is nothing, not even the gist of the text are unclear,The teaching mode of English teaching is only the memorization of English language knowledge and understanding, rather than the understanding of the text content, even if some teachers can content the effect to make detailed explanation and analysis of the text, but the subject status of students in the process has not been reflected, students just learn the knowledge, and no ability to improve.RICH teaching mode has changed the traditional mode of the teaching, especially in the demand of the development of integrated curriculum for English majors and the background, the English class teaching not only limited to the textbooks, also should be contained in the content the text of culture, thoughts, emotions, etc fully tapped.RICH teaching model in the application of English major integrated curriculum development, make the English class began the transformation of many aspects:First of all, English classroom teaching is no longer around the text language knowledge teaching, the text content contained in the text behind the profound implication, reflected in the special foreign cultural background, and is the author's thoughts and feelings of the rich will be able to get good mining and interpretation;Secondly, English classroom teaching is no longer a teacher about teaching, but teachers guide students to active exploration of teaching, the teacher points given the text research clues and students based on teachers' team collaborative discussions and research, and then to learn the identity of the master himself to find out;Again, English teaching is no longer just about English discipline teaching, but also a variety of subjects such as literature, history, political integration of the rich class, the text of literature, history, science and technology knowledge to students through self-exploration, cooperation, explore the form of finding and summary of relevant materials, this makes the students can not only learn language skills, knowledge, can also study other related disciplines of knowledge, and the development of the comprehensive course for English major has provided the possibility and feasibility.

The reform of the teaching methods.

RICH teaching mode based on the advanced teaching idea, the teaching contents and so on various aspects have a makeover of change, on the method of teaching is no exception.First of all, RICH teaching mode in the development of integrated curriculum in English major advocated by the teachers and students both sides negotiate to determine teaching Settings 。 Teaching includes the determination of the teaching goal, teaching content choice, the choice of teaching methods and teaching assessment and evaluation, etc., let the students to participate in the teaching link of whole process can enhance the consciousness of students' character, and to participate in the enthusiasm of learning,This can not only strengthen students consciousness of students, more can let students experience the role of the teacher, the responsibility of the teacher's role in the school of experience and role, so as to understand the function of teachers' role, then to both teachers and students in learning status of professional English learning, and by the transformation of the role in the learning process, improve the ability of empathy, and independent ability to participate in cooperative learning.Second, teachers in the role in the development of integrated curriculum for English majors should be "teach them to fish", not "teach them to fish",

Teachers should put the emphasis of the teaching in classroom teaching to teach students to learn and to explore the methods above, rather than on the interpretation of professional English language knowledge and instilling it,RICH cooperation learning teaching mode for middle school students through the group between form good learning habits and improve the ability of autonomous learning, for the further development of comprehensive course for English majors have laid a good foundation.The development of the comprehensive course requires students to develop English majors learning resources, and can through the team cooperation and resource sharing to present in class, in the form of the RICH teaching mode in the important embodiment of English major integrated curriculum development, andNormally, this unique teaching method has the following several parts: form cooperative groups, determine the discussion and exploration of subjects, find topics related to many fields of information, edit the data in a reasonable manner, making display posters, group representatives, oral report, to mutual cooperation between group and small written 
write research papers.

\section{RICH teaching in English major in the development of integrated curriculum evaluation system}

RICH in the development of integrated curriculum in the English teaching mode in the teaching evaluation system construction has a very complete theoretical system and practice experience, and formed a relatively complete system, specific evaluation pattern mainly can be divided into formative assessment and summative assessment and three kinds of self-evaluation and mutual evaluation.

In the RICH development of integrated curriculum of English major teaching mode, the formative assessment refers to play the role of guidance teachers in English teaching, the teacher to student's guide and inspire the spread to the whole process of students' learning, and the specific period, periodic evaluation of student learning, giving students feedback and evaluation in time, the next phase of the study provide guidance for students. The evaluation of teachers on students' learning should focus on the following nodes: is the first node in the group, according to a research topic after teacher give after discuss the conception of conception, teacher to student's conception and research methods and ideas for evaluation and adjustment suggestion;The second node is mainly focused on the students according to the research train of thought and collection of related data, the teacher is given according to the results of the student's information integration research train of thought on the evaluation and guidance, and the next phase of the research direction is given;Third node occurs mainly in the students according to the teacher on the stage carries on the practice research, research direction is given as a word in the English text theme exploration and discussion, the teacher can research steps and methods to the student to give guidance and advice;In fact, the students in group cooperative study and exploration, and there is no strict sense of right or wrong, but because the student to the comprehensive course for English study is not enough to adapt to, familiar with the application of RICH teaching mode is not enough, so teachers in the process of formative assessment should be focused on improving students participate in group work initiative and enthusiasm, explore the pros and cons of research results for too much criticism, but should be put forward in the form of euphemism suggestion, so students' learning confidence and motivation.

Summative assessment is our traditional mode of education assessment and evaluation, the assessment and evaluation model although there are many disadvantages, such as focus on the student's written examination results, and not pay attention to the students' learning process, also don't care about the students' learning needs and the emotion, such as serious lack of student's humanistic care,But due to the long-term under the exam-oriented education system in our country, and because of the education in our country population, currently there is no could effectively evaluate students' language acquisition convenient degree of more effective methods, so summative assessment and evaluation model in a short period of time will not be replaced.Since cannot replace the summative evaluation of the status and role, so had to start from the summative assessment itself to find a solution to the problem.Summative assessment is in a relatively long time to the student assessment and evaluation of learning outcomes, such as school in the final test is a typical embodiment of summative assessment and evaluation mode, but the summative evaluation itself can also be suitable for the creative use of,As in RICH teaching mode, the achievement of summative evaluation refers to the end of the semester monographs, monographic includes students comprehensive course for English majors in class when the record of the learning process, team cooperation and the record of the research process and teacher evaluation, the result of the research results and experience of students in the learning process, and so on, This kind of summative assessment and examination results obvious differences in the traditional sense.This kind of teaching mode of summative evaluation to avoid the error evaluation to the students learning ability, through the review and reflection on the students throughout the learning process, to encourage students to self reflection and evaluation of the whole learning process, but also can promote the language expression and logical thinking ability, comprehensive course is to enhance English 
learning interest and enthusiasm of the important way.Teachers in the process of instruction and communication with students and to the students' humanistic concern and the spiritual teachings.

\section{References}

[1] Lee Ching. RICH teaching pattern in the independent college comprehensive English teaching the application [J].Journal in the days, 2011, 12:133-134.

[2] Huang Aifeng, ZhengZhi, and Hu Mei-Xin. RICH English teaching mode, teachers' professional comprehensive English course reform exploration [J]. Foreign language teaching, 2000, 11:7 to 13.

[3] Zhao Lin.RICH university English teaching pattern of new evaluation system research [J]. Journal of shenyang agricultural university (social science edition), 2014, 466:466-470. 